JURNAL SEHAT MASADA VOLUME XV NOMOR $1 \quad$ Januari $2021 \quad$ ISSN : 1979-2344

\title{
FAKTOR KEJADIAN CACINGAN PADA BALITA STUNTING DI KECAMATAN PAMULIHAN KABUPATEN SUMEDANG
}

\author{
Fardila Elba \\ Departemen Ilmu Kesehatan Masyarakat, Fakultas Kedokteran Universitas Padjadjaran. \\ fardilaelba@yahoo.com,
}

\begin{abstract}
ABSTRAK
Menurut Riskesdas di Indonesia penyakit kecacingan masih banyak terjadi terutama pada anak dengan prevalensi tahun 2013 sebesar 22,6\%. Dampak yang terjadi jika balita terus menerus terinfeksi cacing salah satunya adalah stunting. Penelitian ini bertujuan untuk mengetahui perbandingan kejadian kecacingan pada balita (12-59 bulan) stunting dan non stunting di Desa Cijeruk Kecamatan Pamulihan Kabupaten Sumedang Tahun 2019. Penelitian analitik ini menggunakan desain case control. Total sampel berjumlah 180 balita dimana 65 balita termasuk dalam kelompok kasus yang diambil dengan metode total sampling dan sebanyak 120 balita termasuk dalam kelompok kontrol yang diambil dengan metode proportionate stratified random sampling. Instrumen penelitian menggunakan kuesioner dan pemeriksaan laboratorium. Hasil penelitian perbandingan kejadian kecacingan ini menunjukan terdapat 2 responden $(1,1 \%)$ positif mengalami kecacingan dan 178 responden $(98,8 \%)$ tidak mengalami kecacingan. Simpulan penelitian ini adalah tidak terdapat hubungan antara kejadian kecacingan terhadap kejadian stunting di Desa Cijeruk yang dilihat berdasarkan uji statistik $(p=1,000)$. Kata Kunci : Kecacingan, Stunting, Balita.
\end{abstract}

\begin{abstract}
According to Riskesdas in Indonesia, helminthiasis is also still common, especially in children with a prevalence in 2013 of 22.6\%. The impact that occurs if a toddler is continuously infected with worms, one of which is stunting. This study aims to compare the incidence of helminthiasis in toddlers (12-59 months) stunting and non-stunting in Cijeruk Village, Pam taken by the total sampling method and as many as 120 toddlers included in the control group taken by the proportionate stratified random sampling method. Research instruments using questionnaires and laboratory examinations.The results of a comparative study of the incidence of helminthiasis showed that there were 2 respondents (1.1\%) positive had a helminthiasis and $178(\%)$ had no helminthiasis. The conclusion of this study is that there is no relationship between the incidence of helminthiasis on the incidence of stunting in Cijeruk Village, which is seen based on statistical tests $(p=1,000)$.
\end{abstract}

Keywords : Worming, Stunting, Toddler.

\section{PENDAHULUAN}

Balita adalah usia anak di bawah lima tahun atau biasa menggunakan perhitungan bulan yaitu 12-59 bulan. Para ahli mengatakan bahwa usia balita sebagai usia tahapan perkembangan anak yang cukup rentan terhadap berbagai serangan penyakit. ${ }^{1}$ Salah Jurnal Penelitian Kesehatan STIKes Dharma Husada Bandung satu penyakit yang masih banyak terjadi di Indonesia terutama pada balita adalah penyakit kecacingan. Kecacingan merupakan penyakit infeksi yang disebabkan oleh parasit berupa cacing. ${ }^{2}$ Menurut WHO tahun 2011 lebih dari 2 miliar orang dan 880 juta diantaranya yaitu anak di dunia terinfeksi kecacingan. 
JURNAL SEHAT MASADA VOLUME XV

Berdasarkan data tersebut prevalensi terbesar terjadi pada anak sehingga kecacingan merupakan salah satu penyakit infeksi yang menjadi masalah kesehatan di dunia. ${ }^{3}$ Menurut Riskesdas di Indonesia penyakit kecacingan juga masih banyak terjadi terutama pada anak dengan prevalensi tahun 2013 sebesar 22,6\%. ${ }^{4}$

Salah satu penyakit kecacingan yang sering terjadi di dunia adalah penyakit cacing yang ditularkan melalui tanah atau disebut juga Soil Transmitted Helminth (STH). Ada tiga jenis cacing yang penularannya melaui tanah, yakni cacing gelang (Ascaris lumbricoides), cacing cambuk (Trichuris trichiura) dan cacing tambang (Necator americanus, dan Ancylostoma duodenale). Infeksi cacing yang ditularkan melalui tanah ditemukan di daerah dengan iklim yang lembab di mana sanitasi dan kebersihan buruk. Seseorang dapat terinfeksi cacing gelang dan cacing cambuk ketika tangan atau jari seseorang memiliki kotoran yang terkontaminasi oleh telur cacing kemudian meletakan jari dan tangan di mulut atau dengan mengonsumsi sayuran dan buahbuahan yang belum dimasak, dicuci, atau dikupas dengan hati-hati, karena pada saat itu telur cacing gelang dan cacing cambuk yang berasal dari tanah akan dicerna. ${ }^{5}$ Sedangkan infeksi cacing tambang ditularkan dengan berjalan tanpa alas kaki di tanah yang terkontaminasi oleh cacing tambang. Salah satu jenis cacing tambang (Anclostoma duodenale) juga dapat ditularkan melalui konsumsi larva. ${ }^{5}$
Hal ini dapat terjadi jika pengetahuan ibu mengenai perilaku hidup bersih dan sehat masih kurang. ${ }^{22}$ Orang yang terinfeksi cacing ringan biasanya tidak memiliki gejala. Sedangkan infeksi cacing yang berat dapat menyebabkan berbagai masalah kesehatan, termasuk sakit perut, diare, kehilangan darah dan protein, prolaps rektum, dan keterbelakangan pertumbuhan fisik dan kognitif. ${ }^{5}$ Dampak yang terjadi jika balita terinfeksi cacing maka infeksi dapat berkontribusi pada anemia, defisiensi vitamin A, penyumbatan usus, keterlambatan perkembangan, kekurangan gizi, gangguan pertumbuhan. ${ }^{6}$ Stunting merupakan salah satu contoh gangguan pertumbuhan yang terjadi pada anak. Balita stunting adalah balita yang memiliki nilai status gizi $(\mathrm{TB} / \mathrm{U})$ berada pada ambang batas atau Z-score < 2 SD s/d -3 SD kategori pendek (stunted) dan $<-3$ SD kategori sangat pendek (severely stunted). ${ }^{8}$

Berdasarkan Pemantauan Status Gizi (PSG) pada 2017, prevalensi balita stunting di Indonesia dari 34 provinsi hanya ada 2 provinsi yang berada di bawah batasan WHO, yakni Yogyakarta $(19,8 \%)$ dan Bali $(19,1 \%)$. Provinsi lainnya memiliki kasus dominan tinggi dan sangat tinggi sekitar 30\% hingga 40\%. ${ }^{9}$ Khusus di Provinsi Jawa Barat diketahui presentase stunting sebesar 29,2 persen. $^{10}$ Berdasarkan data balita stunting di Kabupaten Sumedang, terdapat $28 \%$ atau 30 ribu kasus stunting. ${ }^{11}$ Sedangkan berdasarkan data balita stunting dari UPT Puskesmas Pamulihan di desa Cijeruk bulan febuari tahun 2018 ada 
sebanyak 83 balita stunting dari 434 balita yang ada di desa Cijeruk. ${ }^{12}$

Beberapa faktor penyebab stunting diantaranya gizi buruk yang dialami ibu hamil dan balita, kurangnya pengetahuan ibu tentang kesehatan dan gizi sebelum dan pada masa kehamilan serta setelah melahirkan, kurangnya akses bersih dan sanitasi, kurangnya asupan makanan bergizi, memiliki penyakit infeksi, dan lain-lain. ${ }^{13}$ Dampak yang ditimbulkan dari stunting untuk jangka pendek adalah terganggunya perkembangan otak, kecerdasan, gangguan pertumbuhan fisik, dan gangguan metabolisme dalam tubuh. Dalam jangka panjang akibat buruk yang akan timbul adalah menurunnya kemampuan kognitif dan prestasi belajar, menurunnya sistem kekebalan tubuh sehingga mudah sakit, dan resiko tinggi untuk munculnya penyakit diabetes, kegemukan, penyakit jantung dan pembuluh darah, kanker, stroke, dan disabilitas pada usia tua. ${ }^{13}$

Berdasarkan uraian diatas, maka peneliti tertarik untuk melakukan penelitian terhadap balita di Cijeruk untuk mengetahui "Perbandingan Kejadian Kecacingan Pada Balita Stunting Dan Non Stunting Di Kecamatan Pemulihan Kabupaten Sumedang."

\section{METODOLOGI}

Penelitian ini menggunakan metode penelitian perbandingan dan desain penelitian dengan pendekatan kasus kontrol yang dilakukan pada bulan juli 2019 pada balita di Desa Cijeruk. Pemilihan sampel pada kelompok kasus menggunakan total sampling sedangkan untuk kelompok kontrol digunakan proportionate stratified random sampling. Kriteria inklusi pada penitilian ini adalah semua balita yang berusia 12 sampai 59 bulan, semua balita yang tinggal di Desa Cijeruk Kecamatan Pamulihan Kabupaten Sumedang Tahun 2019 dan kriteria eksklusi nya adalah ibu yang tidak dapat melakukan pengambilan feses pada anaknya. Pengambilan data yang digunakan pada penelitian ini adalah data primer. Data primer digunakan untuk dapat memisahkan antara kelompok balita stunting dan non stunting dengan cara pengukuran tinggi badan kemudian dibagi umur, dan untuk mengetahui apakah balita tersebut menderita penyakit kecacingan peneliti mengambil sampel feses pada setiap balita. Bila ditemukan telur cacing ataupun cacing peneliti segera merujuk balita tersebut ke puskesmas untuk mendapatkan perawatan lebih lanjut. Inform concent dan pemberitahuan cara pengambilan sampel feses dilakukan 1 hari sebelum sampel feses diambil oleh peneliti untuk diteliti. Setelah melakukan inform concent secara door to door dan responden setuju menjadi responden penelitian selanjutnya peneliti. Membagikan kuesioner untuk biodata dan dilanjutkan dengan pengukuran tinggi badan pada setiap balita. Keesokan harinya peneliti mengambil setiap sampel feses secara door to door, sampel tersebut dibawa ke Laboratorium Mikrobiologi dan Parasitologi FK UNPAD dan dilakukan pemeriksaan sampel feses dengan metode direct slide. Selanjutnya memasukan hasil pemeriksaan ke dalam lembar kuesioner. 
Lalu data diolah menggunakan SPSS dan dianaliasi menggunakan analisa univariat dan bivariat kemudian data disajikan dalam bentuk tabel distribusi frekuensi, dan perbandingan.

\section{HASIL DAN PEMBAHASAN}

Berdasarkan hasil penelitian dapat diketahui hasil sebagai berikut.

\section{Kejadian stunting}

Tabel 1. Distribusi Frekuensi Berdasarkan Karakteristik Balita terhadap Stunting

\begin{tabular}{lcccc}
\hline & \multicolumn{2}{c}{ Stunting } & \multicolumn{2}{c}{ Non stunting } \\
Karakteristik & $\mathrm{N}$ & $\%$ & $\mathrm{n}$ & $\%$ \\
\hline Usia & & & & \\
$12-36$ bulan & 22 & 12,22 & 65 & 36,11 \\
27-59 bulan & 38 & 21,01 & 55 & 30,66 \\
Jenis kelamin & & & & \\
Perempuan & 31 & 17,22 & 54 & 30 \\
Laki-laki & 29 & 16,11 & 66 & 36,67 \\
\hline
\end{tabular}

Berdasarkan tabel 1, terlihat bahwa usia 37-59 bulan merupakan usia terbanyak yang mengalami stunting dan perempuan menempati jenis kelamin terbanyak yang mengalami stunting. Stunting merupakan suatu kondisi kekurangan gizi kronis yang dimulai sejak 1000 hari pertama kehidupan. ${ }^{31}$ Menurut kajian penelitian sebelumnya bayi berat lahir rendah (BBLR), riwayat air susu ibu (ASI) eksklusif, dan prematuritas merupakan faktor yang berhubungan dengan stunting di Indonesia. ${ }^{31,32}$ Didukung oleh penelitian lain BBLR dan riwayat penyakit infeksi penyakit merupakan faktor yang paling mempengaruhi kejadian stunting, dalam penelitiannya terdapat hubungan yang signifikan antara BBLR dan riwayat penyakit infeksi terhadap kejadian stunting pada anak usia 12-60 bulan. ${ }^{30}$ Upaya percepatan penurunan atau pencegahan stunting dilakukan dalam bentuk intervensi gizi sensitif dan intervensi gizi spesifik. Intervensi gizi spesifik lebih fokus pada upaya pencegahan stunting dalam kurun waktu 1000 HPK, meliputi diantaranya pemberian makan tambahan untuk mengatasi Kekurangan Energi Kronis (KEK) pada ibu hamil, pemberian tablet tambah darah pada ibu hamil, ASI Eksklusif, suplementasi zink, fortifikasi zat besi, pemberian obat cacing dan vitamin A, menangani gizi buruk dan penanggulangan penyakit infeksi. Sebagian besar intervensi ini melibatkan tenaga kesehatan serta dapat dilakukan di Posyandu dengan koordinasi tenaga kesehatan dari Puskesmas. ${ }^{33}$

\section{Kejadian kecacingan}

Tabel 2. Distribusi Frekuensi Berdasarkan Karakteristik Balita terhadap Kecacingan

\begin{tabular}{ccccc}
\hline & \multicolumn{2}{c}{ Kecacingan } & \multicolumn{2}{c}{ Tidak } \\
kecacingan \\
Karakteristik & $\mathrm{n}$ & $\%$ & $\mathrm{n}$ & $\%$ \\
\hline Usia & & & & \\
12-36 bulan & 0 & 0 & 87 & 48,33 \\
27-59 bulan & 2 & 1,11 & 91 & 50,56 \\
Jenis kelamin & & & & \\
Perempuan & 1 & 0,55 & 84 & 46,68 \\
Laki-laki & 1 & 0,55 & 94 & 52,22 \\
\hline
\end{tabular}

Berdasarkan tabel 2, dapat dilihat terdapat 2 orang balita $(1,1 \%)$ yang terindentifikasi positif kecacingan yang diakibatkan oleh cacing gelang dari 180 balita. Infeksi kecacingan pada penelitian ini termasuk dalam kategori ringan karena telur yang ditemukan masing-masing hanya sebanyak 2 dan 4 telur 
JURNAL SEHAT MASADA

VOLUME XV

pada sampel tinja subjek. Hal ini sesuai dengan perhitungan tingkat infeksi ascaris, dikatakan ringan dikarekan jumlah telur ${ }^{27}$ Infeksi cacing yang ditularkan melalui tanah sering ditemukan di daerah dengan iklim yang lembab. Kondisi alam atau lingkungan geografi juga mempengaruhi angka kejadian kecacingan. ${ }^{5}$

Pengambilan data penelitian ini dilakukan pada musim kemarau (bulan juli) sehingga angka kejadian infeksi kecacingan pada penelitian ini sangat rendah. Hal ini sejalan dengan hasil penelitian yang dilakukan di Kota Palembang tahun 2015 di musim kemarau pada subjek anak usia 5- 12 tahun memiliki angka kejadian infeksi kecacingan yang rendah (hanya 6,8\%). ${ }^{27}$ Hal ini dikarenakan musim kemarau dan kondisi tanah kering tidak sesuai untuk perkembangan Soil Transmitted Helminths (STH). ${ }^{5}$ Selain kondisi lingkungan, buruknya personal higiene seseorang yang menyebabkan kecacingan yaitu perilaku ibu yang tidak mencuci bersih makanan yang akan dimakan oleh balita dan perilaku balita yang tidak mencuci tangan dengan sabun setelah buang air besar, tidak mencuci kaki dan tangan setelah bermain di tanah, tidak menggunakan alas kaki ketika keluar rumah dan kebersihan kuku tidak dijaga dengan baik. ${ }^{5}$ Menurut ibu subjek yang terinfeksi kecacingan, subjek memiliki kebiasaan sering bermain tanpa memakai alas kaki dan jarang mencuci tangan dengan sabun sebelum makan maupun setelah buang air besar. Selan itu, subjek belum pernah mengkonsumsi obat cacing sebelumnya.

Perilaku BAB di sembarang tempat juga akan menyebabkan terjadinya pencemaran tanah atau lingkungan oleh feses yang mengandung telur cacing. ${ }^{5}$ Pada penelitian ini ditemukan bahwa perilaku hygiene masyarakat Desa Cijeruk sudah mulai meningkat terlihat dengan masyarakat Desa Cijeruk sudah tidak buang air besar (BAB) disembarang tempat.

Upaya yang nyata untuk meningkatkan kualitas sumber daya balita di Desa Cijeruk yaitu program jangka pendek dengan membunuh cacing melalui pengobatan. Program pemerintah ini dimulai dengan mengurangi prevalensi infeksi cacing dengan membunuh cacing melalui pengobatan sehingga intensitas infeksi cacing menghilang. ${ }^{28}$

Program pemberian obat cacing oleh Puskesmas Pamulihan menjadi salah satu tindakan preventif yang menyebabkan rendahnya angka kejadian infeksi cacing di lokasi penelitian. Pengobatan dilakukan di posyandu masing - masing, pihak Puskesmas memberikan obat yang diperoleh dari pemerintah dan harus diminum di depan petugas serta tidak boleh di bawa pulang. Obat yang diberikan oleh Puskesmas Pamulihan adalah Albendzole, untuk usia 2-12 tahun diberikan $400 \mathrm{mg}$ albendazole sedangkan untuk usia 1-2 tahun diberikan albendazole dengan dosis $200 \mathrm{mg}$.

Obat ini mempunyai spektrum luas untuk membunuh cacing yang ada di tubuh 
manusia termasuk cacing pada pencernaan.

35. Albendazole juga memiliki efek vermisida, ovisida dan larvasida dengan mempengaruhi parasit dan menghambat fungsi absorbsi yang penting pada parasit tersebut. ${ }^{36}$ Dua indikator yang menentukan efektivitas antelmintik pada pengobatan manusia adalah angka kesembuhan dan penurunan jumlah telur. ${ }^{37}$

Kegiatan pemberian obat cacing ini turut andil dalam menurunkan prevalensi kecacingan di Desa Cijeruk dapat dilihat dari rendahnya angka kecacingan yang disebabkan Ascaris lumbricoides dan tidak ditemukannya kecacingan yang disebabkan cacing Hookworm.

Namun, menurut penelitian lain pemberian obat menggunakan albendazole tidak efektif untuk beberapa jenis cacing seperti untuk cacing Trikuris trichiura dan Hymenolepis sp. Untuk kecacingan Trikuris trichiura pengobatan yang sebaiknya diberikan adalah albendazole dengan dosis $400 \mathrm{mg}$ selama tiga hari atau mebendazol $100 \mathrm{mg} 2 \mathrm{x}$ sehari selama 3 hari berturut-turut. ${ }^{34}$

Didukung oleh penelitian lain Albendazole $400 \mathrm{mg}$ yang diberikan selama tiga hari berturut-turut dan dua hari berturutturut memiliki manfaat yang lebih baik dibandingkan albendazole $400 \mathrm{mg}$ selama satu hari untuk infeksi Trikuris trichiura. 38 Sehingga dapat disimpulkan Albendazole 400 mg selama satu hari efektif untuk mengatasi askariasis dan infeksi hookworm, sedangkan albendazole dua hari berturut-turut dapat menjadi pilihan albendazole yang lebih baik untuk mengatasi infeksi trikuriasis dengan intensitas ringan dan sedang. ${ }^{38}$

\section{Perbandingan kejadian kecacingan pada balita stunting dan non stunting}

Tabel 3. Perbandingan Kejadian Kecacingan pada Balita Stunting dan Non Stunting

\begin{tabular}{llllllll}
\hline Kejadian & \multicolumn{4}{c}{ Stunting } & \multicolumn{2}{c}{ Total } & $\boldsymbol{p}$ \\
\cline { 2 - 7 } kecacingan & \multicolumn{2}{c}{ Ya } & \multicolumn{2}{c}{ Tidak } & & \\
\cline { 2 - 7 } & $\mathrm{n}$ & $\%$ & $\mathrm{n}$ & $\%$ & $\mathrm{~N}$ & $\%$ & \\
Positif & 1 & 0,56 & 1 & 0,56 & 2 & 1,12 & 1,000 \\
Negatif & 59 & 32,77 & 119 & 66,11 & 178 & 98,88 & \\
Total & 60 & 33,33 & 120 & 66,67 & 180 & 100 & \\
\hline
\end{tabular}

Berdasarkan tabel 2, terdapat 2 $(1,12 \%)$ balita yang mengalami kecacingan, yang terdiri dari $1(0,56 \%)$ balita stunting dan $1(0,56 \%)$ balita non stunting. Berdasarkan uji statistik fisher exact test $(p=1,000)$ tabel ini menunjukan tidak ada hubungan yang bermakna antara kejadian kecacingan dengan stunting pada balita di Desa Cijeruk Kecamatan Pamulihan Kabupaten Sumedang.

Penelitian ini menunjukan hasil tidak ada hubungan antara kejadian infeksi kecacingan dan stunting pada balita di Desa Cijeruk Kecamatan Pamulihan Kabupaten Sumedang dikarenakan subjek pada penelitian ini rata-rata sudah meminum obat cacing yang diberikan oleh Puskesmas. Walaupun pada penelitian ini tidak berhubungan menurut sebuah penelitian riwayat penyakit infeksi merupakan faktor yang paling mempengaruhi kejadian stunting dalam penelitiannya menyatakan bahwa terdapat hubungan yang signifikan antara riwayat penyakit infeksi penyakit terhadap kejadian stunting pada anak usia 12-60 bulan. ${ }^{30}$ 
Didukung oleh penelitian lain yang menyatakan bahwa riwayat diare yang terjadi secara sering dalam 3 bulan terakhir dan praktik higiene yang buruk meningkatkan risiko sebesar 3,619 dan 4,808 kali terhadap kejadian stunting pada balita usia 24-59 bulan. Dimana diare tersebut disebabkan oleh adanya infeksi pencernaan.

\section{KESIMPULAN}

Berdasarkan penelitian yang telah dilakukan balita stunting di Desa Cijeruk tentang perbandingan kejadian kecacingan pada balita stunting dan non stunting maka dapat disimpulkan sebagai berikut:

1) Pada karakteristik balita stunting, terdapat $17,22 \%$ balita berjenis kelamin perempuan dan terdapat $21,01 \%$ balita berusia 37-59 bulan. Pada karakteristik balita kecacingan terdapat $1,11 \%$ berusia 37-59 bulan.

2) Berdasarkan uji statistik $(p=1,000)$ yang berarti tidak ada hubungan yang bermakna antara kejadian kecacingan dengan kejadian stunting pada balita di Desa Cijeruk Kecamatan Pamulihan Kabupaten Sumedang

3) Perbandingan kejadian kecacingan pada balita stunting dan non stunting adalah $1: 2$.

\section{DAFTAR PUSTAKA}

1. Kementrian Kesehatan Republik Indonesia. Situasi Kesehatan Anak Balita di Indonesia. Jakarta : Pusat Data dan
Informasi Kementrian Kesehatan RI 2015.

2. Rowardho, D., \& Ismail, T. S. (2018). Keberadaan Telur Cacing Usus pada Kuku dan Tinja Siswa Sekolah Alam dan Non Alam. Jurnal Kesehatan Masyarakat Indonesia, 10(2), 18-25.World Health Organization. Helminthiases S.As a Public Health Problem in Children. 2011.

3. Kementrian Kesehatan. Riset Kesehatan Dasar Jakarta 2013.

4. Center for Disease Control and Prevention. Parasite Soil-transmitted helminths. 2013.

5. Center for Disease Control and prevention. Gateway to Health Communication \& Social Marketing Practice. 2017.

6. Schmidt, C. W. (2014). Beyond malnutrition: the role of sanitation in stunted growth.Kementrian Kesehatan Republik Indonesia. Buku Saku Pemantauan Status Gizi (PSG) 2017.

7. Kementrian Kesehatan Republik Indonesia. Penurunan Stunting Jadi Fokus Pemerintah. 2018.

8. Lukihardianti A. Sebanyak 130 Desa di Jabar Hadapi Masalah Stunting. Republika. 2018.

9. Baihaqi H. 28 Persen Balita di Sumedang Mengalami Stunting Tribun News 2018.

10.Puskesmas. Data Status Gizi Balita Desa Cijeruk 2018.

11.Kemendesa. Buku Saku Desa dalam Penanganan Stunting. Jakarta: Kementerian Desa, Pembangunan Daerah Tertinggal, dan Transmigrasi Republik Indonesia. 2017.

12.Center for Disease Control and promotive. Parasites - Ascariasis. 2018.

13.Kementrian kesehatan. Cegah Stunting Dengan Perbaikan Pola Makan, Pola Asuh dan Sanitasi 2018.

14.Silas, L., Rantetampang, A. L., Tingginehe, R., \& Mallongi, A. (2018). The Factors Affecting Stunting Child under Five Years in Sub Province Mimika. Education, 13(87), 13..

15.Adelia, F. A., Widajanti, L., \& Nugraheni, S. A. (2018). Hubungan Pengetahuan Gizi Ibu, Tingkat Konsumsi Gizi, Status Ketahanan Pangan Keluarga dengan 
Balita Stunting (Studi pada Balita Usia 24-59 Bulan di Wilayah Kerja Puskesmas Duren Kabupaten Semarang). Jurnal Kesehatan Masyarakat (e-Journal), 6(5), 361-369.

16.Merryana Adriani, S. K. M., Wirjatmadi, B., MS, M., \& Gk, S. (2014). Gizi dan Kesehatan Balita: peranan mikro zinc pada pertumbuhan balita.

17.Hafid, F., \& Nasrul, N. (2016). Faktor Risiko Stunting Pada Anak Usia 6-23 Bulan di Kabupaten Jeneponto (Risk Factors of Stunting among Children Aged 6-23 Months in Jeneponto Regency). Indonesian Journal of Human Nutrition, 3(1), 42.

18.Rosmalina, Y., Luciasari, E., Aditianti, A., \& Ernawati, F. (2018). Upaya pencegahan dan penanggulangan batita stunting: systematic review. Gizi Indonesia, 41(1), 1-14.

19.Kementrian Kesehatan Republik Indonesia. Keputusan Menteri Kesehatan Republik Indonesia Nomor 10 Tahun 2010. Tentang Standar Antopometri Penilaian Status Gizi Anak. 2010.

20.Subagiyono, S. (2018). ANALISIS TINGKAT PENGETAHUAN DAN PERILAKU IBU DALAM UPAYA PENCEGAHAN PENYAKIT KECACINGAN PADA ANAK DI TK PANTI DEWI TANJUNG KALITIRTO BERBAH SLEMAN. JURNAL KESEHATAN MASYARAKAT, 11(1).

21.Aridiyah, F. O., Rohmawati, N., \& Ririanty, M. (2015). Faktor-faktor yang Mempengaruhi Kejadian Stunting pada Anak Balita di Wilayah Pedesaan dan Perkotaan (The Factors Affecting Stunting on Toddlers in Rural and Urban Areas). Pustaka Kesehatan,3(1), 163170.

22.Lemeshow, S., Hosmer, D. W., Klar, J., \& Lwanga, S. K. (1997). Besar sampel dalam penelitian kesehatan. Yogyakarta: Gajah Mada University.

23.Direktorat Jenderal PP \& PL. Pedoman Pengendalian Kecacingan. Jakarta: Departemen Kesehatan RI; 2012.

24.Natadisastra, D., \& Agoes, R. (2009). Parasitologi kedokteran: ditinjau dari organ tubuh yang diserang. Jakarta: EGC.
25.Kamila, A. D., Margawati, A., \& Nuryanto, N. (2018). HUBUNGAN KECACINGAN DENGAN STATUS GIZI DAN PRESTASI BELAJAR PADA ANAK SEKOLAH DASAR KELAS IV DAN $\mathrm{V}$ DI KELURAHAN BANDARHARJO SEMARANG. Journal of Nutrition College, 7(2), 77-83.

26.Direktorat Jenderal PP \& PL. Pedoman Pengendalian Kecacingan. Jakarta: Departemen Kesehatan RI; 2012.

27. Sutanto, I., Ismid, I. S., Sjarifuddin, P. K., \& Sungkar, S. (2008). Parasitologi kedokteran. Jakarta: Balai Penerbit UI.

28. Wati, L., Monarisa, M., \& Rikandi, M. (2019). Pengaruh Berat Badan Lahir Rendah dengan Kejadian Stunting pada Anak Usia 12-23 Bulan di Wilayah Kerja Puskesmas Lubuk Buaya Padang Tahun 2019. Jurnal Ilmiah Universitas Batanghari Jambi, 19(3), 615-619.

29. Aryastami, N. K., Shankar, A., Kusumawardani, N., Besral, B., Jahari, A. B., \& Achadi, E. (2017). Low birth weight was the most dominant predictor associated with stunting among children aged 12-23 months in Indonesia. BMC Nutrition, 3(1), 16.

30.Prawirohartono, E., Nurdiati, D., \& Hakimi, M. (2016). Prognostic factors at birth for stunting at 24 months of age in rural Indonesia. Paediatrica Indonesiana, 56(1), 48-56.

31. Megawati Ginna, Siska Wiramihardja. Peningkatan Kapasitas Kader Posyandu Dalam Mendeteksi Dan Mencegah Stunting Di Desa Cipacing Jatinangor. Dhamakarya. 2019.

32.Fakhrizal, D., Hariyati, E., \& Hidayat, S. (2019). KEJADIAN DAN KEBIJAKAN PENGENDALIAN KECACINGAN DI KABUPATEN HULU SUNGAI UTARA PROV KALIMANTAN SELATAN. Jurnal Kebijakan Pembangunan, 14(1), 31-36.

33. Annisa, I., Damayanti, R., Trianto, D. M., Wiratama, M. P., Wahdini, S., \& Sungkar, S. (2017). Pengaruh Pengobatan Albendazol Dosis Tunggal terhadap Infeksi Soil-Transmitted Helminth dan Status Gizi Anak di Desa Perokonda, 
Sumba Barat Daya. eJournal Kedokteran Indonesia, 5(2), 114-120.

34.Dayan, A. D. (2003). Albendazole, mebendazole and praziquantel. Review of non-clinical toxicity and pharmacokinetics. Acta tropica, 86(2-3), 141-159.

35.Vercruysse J, Albonico M, Behnke J, Kotze A, McCarthy J, Prichard R, dkk. Monitoring antihelminthics efficacy for soil-transmitted helminthes (STH). Geneva: WHO; 2008.

36.Gultom, D. E. (2019). Perbandingan Efikasi Albendazole $400 \mathrm{mg}$ Tiga Hari Berturut-Turut, Dua Hari Berturut-turut dan Satu Hari Terhadap Infeksi Soil Transmitted Helminths.

37.Desyanti, C., \& Nindya, T. S. (2017). Hubungan riwayat penyakit diare dan praktik higiene dengan kejadian stunting pada balita usia 24-59 bulan di wilayah kerja Puskesmas Simolawang, Surabaya. Amerta Nutrition, 1(3), 243251. 